\title{
The Local Wisdom of the Coffee Farming System in Temas Mumanang Village Permata, District Bener Meriah Regency, Nanggroe Aceh Darussalam Province
}

\author{
Puspitawati $^{1}$, Noviy Hasanah ${ }^{2}$, Ayu Febryani ${ }^{3}$, Dedi Andriansyah ${ }^{4}$ \\ \{puspitawati@unimed.ac.id ${ }^{1}$, noviyhasanahfis@unimed.ac.id², ayufebryani@unimed.ac.id ${ }^{3}$,
}

Universitas Negeri Medan, Medan, Indonesia

\begin{abstract}
This study aims to analyze the various local wisdom of the coffee farming system in the Gayo Highlands and the existence of local wisdom in the agricultural system that is applied. In addition to identifying problems faced by farmers and how to handle them in managing agricultural resources in Bener Meriah Regency. This is not only as a form of preserving local knowledge related to the wise use of the environment but also as a solution to solving human and environmental problems. This study uses a qualitative research method with an ethnographic approach. This method was chosen because in carrying out the documentation it is necessary to have a holistic description of a study. Therefore we need data collection techniques in the form of participatory observation, in-depth interviews, life in, and documentation of informant activities related to the agricultural system. In the end, this research leads to the concept of Indonesia as a country that can penetrate the international market in coffee income through a local wisdom system that is still preserved. The results of this study are expected not only for scientific purposes and to answer research problems, but more importantly and significantly can contribute to identifying forms of local wisdom that are still maintained and provide benefits in the lives of local communities.
\end{abstract}

Keywords: local wisdom, coffee farming system

\section{Introduction}

Indonesia is one of the countries in Asia that can penetrate the international level in the coffee trade. Coffee can only grow in tropical climates with a certain height and type of soil. The topographical criteria and requirements that are met are the regions along the equator or the term tropical coffee belt. One of the areas included in this topography and coffeeproducing region in Indonesia, one of which is the Gayo Plateau (DTG) in Aceh Province which is the largest Arabica Coffee production area in Indonesia, even in the entire Asia Pacific region (AEKI) [1].

Plantations are often categorized into two types, namely independent plantations, and industrial plantations [2]. We can see both types of plantations in the Coffee plantations in the Gayo Highlands. In the Gayo Highlands (DTG) region, almost the majority of the people earn a living as coffee farmers. Arabica Coffee is a type of coffee that is widely planted in the Gayo Highlands (DTG) region. Tirsa Said local wisdom becomes potential energy and also a power that can guide the community to develop a set of activities to meet the needs of life that still responds to the conditions of the natural environment [3]. 
Meanwhile, according to Ridwan said local wisdom acts as an interactive space that has been designed in such a way that involves a pattern between humans and humans, as well as humans and nature [4]. Local knowledge which is still largely maintained by farmers Coffee is the idea of the community that is learned directly from nature by considering all the good, bad, and useful for the life activities of farmers. Local knowledge or local wisdom is then inherited to the next generation and becomes an order that can make a major contribution to the production of coffee agriculture.

Local wisdom that is still applied by coffee farmers in the area of Temas Mumanang Village, Permata District, Bener Meriah Regency, Nanggroe Aceh Darussalam has an impact on the quality and quantity of good and maintained coffee harvests. Otto Soemarto sees that local wisdom is not only a product of a local culture that is then passed down from generation to generation but is also related to the development of human life itself[5]. Sukmawati et.al researched the local wisdom of the Kaili community in Central Sulawesi related to the natural environment [6]. The result is a pattern in maintaining harmony in life with Lake Lindu and also the forest around the lake. Ani Susilawati and Dedi Nursyamsi research on local wisdom in the agricultural system in the people of Central Java, known as the Surjan system [7]. The Surjan system turned out to be a combination of local wisdom that was able to collaborate with technological innovations which included water management, selection of adaptive plants, minimum land management, checking swamp planting calendar which turned out to be a way for tidal land farmers to overcome climate problems from a local cultural perspective.

Cepriadi and Kausar Research on Strategies for Maintaining Local Wisdom Paddy Rice in the Village of Bungaraya in the District of Bungaraya Siak District explained the results that there are several stages in the agricultural system that are still maintained by farmers, namely the stages of land clearing by conducting a cooperation system and joint prayer (kenduri) to be given smoothness by Almighty God [8]. Local wisdom develops in ways and practices developed by humans, from their deep understanding of the local environment [9] [10].

\section{Method}

The research method used in this study is a qualitative study [11] with an ethnographic approach in the form of life history and life in [12]. The life history approach is carried out with in-depth interviews about the experiences of the farmers and the families of the farmers. This life history approach model is strengthened by living together and following the activities of farmers when they are engaged in coffee plantations.

Data analysis in this study was divided into several stages that followed the interpretation of data using the Spradley ethnographic model [12], namely: (1) domain analysis; (2) taxonomic analysis; (3) component analysis; and (4) theme analysis. Domain analysis is carried out to obtain a general and holistic picture of the daily lives of female fishermen. Furthermore, the taxonomic analysis carried out after the first step is carried out. This analysis was carried out by collecting observations of participatory participation in the activities of female fishermen while at sea, unstructured interviews, and study of documents relating to the domains studied.

Then the component analysis is done is to look for differences or contrasts and decide which domains must be studied in-depth related to the research. Then the theme analysis becomes the final part which is the link between the various domains (interviews and observations). Analysis of the theme becomes a step to holistically understand the 
"phenomena" that are being studied and their interpretation. So that conclusions and data that are considered important are easier to do.

\section{Results and discussion}

Temas Mumanang village is located in the Permata sub-district of Bener Meriah district which is included in the Gayo Plateau region which is an area of Gayo ethnic origin. The majority of the population earns a living as farmers, especially as coffee farmers. Geographical Conditions Gayo Plateau which is located at an altitude of about 1300 meters above sea level is an ideal environment for the cultivation of arabica coffee plants. This location has become one of the centers of growing Arabica coffee in Indonesia.

At present, the Gayo Highlands region in general, including in this research village, is not only one of the largest Arabica coffee producing places in Indonesia, but also a region of highgrade Arabica coffee production with the best grade known as specialty coffee. The success of coffee farmers in maintaining the quality and quantity of their coffee yields has shown the success of the farming system itself. The farming system carried out by Coffee farmers in Temas Mumanang Village can be categorized as modern. But on the other hand, much traditional knowledge that can support the garden management system related to certain aspects is still maintained. Therefore, in the practice of managing coffee plantations in this area, although farmers now use modern agricultural equipment, some local knowledge is also followed by farmers.

Maintaining traditional knowledge based on local wisdom is inseparable from the methods applied by farmers, most of the knowledge is indeed simple but full of religious values, solidarity, and wisdom. So that the system is still maintained so that it can still have a good impact as it has been ongoing and become local wisdom on coffee farmers in the Gayo Highlands itself. From the results of observations and in-depth interviews with coffee farmers who have their plantations, several things can be formulated as a form of the local wisdom system. This item is then classified into three parts, namely (1) the land clearing and planting phase, (2) the phase maintenance and (3) harvest phase.

Traditional agricultural activities are usually always preceded by land clearing activities. The farmers usually before carrying out tree felling in the forest called muger. Before the muger process takes place before the farmers will carry out the festivity by following applicable norms. Kenduri aims to ask permission from the landowners which they call tuen tanoh to avoid the calamities and unkindness that are considered to be able to override their smoothness when managing the land. The festivity is filled with a joint prayer program led by someone who has supernatural expertise which will serve as a liaison between the forest clearing and the land. Besides, usually also attended Imem (priest/cleric) village who will lead the prayer during the festivity ceremony took place.

In the feast ritual, they must prepare several types of food that are used as offerings, namely: bertéh namely rice grains that are unshaken until the seeds burst and resemble the form of popcorn (bertih), cooked glutinous rice, four bananas, and one boiled egg. All these foods are combined and served in a platter. The ritual is usually held in the area of land to be opened. The festivity is also done by inviting relatives and neighbors to jointly work on land clearing.

At present, the festivity as explained above has rarely been carried out by people, not only due to the reduced process of clearing primary / muger forests carried out due to the 
increasingly limited forest areas in this area, but also the increasing knowledge of their religion which considers such acts as shirk which is forbidden by religion. Nevertheless, the activity to recite prayers when starting planting is still being done. The use of the required ingredients is usually replaced by providing food to be eaten together after the prayer process is finished. But in practice, some farmers do not perform the festivity ritual, just enough to simply say goodbye or ask permission. In this farewell, you can use the pronunciation by following the wishes of the farmer and there are no mantras or forms of greeting that are standard and specific.

At this time, in the process of land clearing, farmers have used modern tools, such as a chainsaw machine (electric saw) which is considered to make logging easier than using an ax. But the use of this chainsaw usually only takes place in the process of clearing the primary forest/muger only. Although it is now increasingly rarely carried out, in some places, there are still a small number of residents who carry it out. Only, this tool is rarely used by farmers who do land clearing activities with the Tamas Mude system (secondary forest clearing, ie land that has been cleared previously by people). This system makes the farmers only enter in the advanced phase because land clearing has been carried out by the landowner when the farmers buy the land. Then in the next stage, the farmers no longer perform the feast ritual or say goodbye.

In every process of carrying out all their work, the Gayo ethnic group is traditionally familiar with the cooperation system called manganlo. Work together or how to work together called this manganlo, is a way to work together to do the cultivation of plants in a way together alternately in each of the group members who have joined. Of course, this is in addition to helping the work of opening land feels lighter, but the bond of kinship and solidarity is tighter. So that fostering concern for fellow farmers and can later exchange ideas relating to coffee management. Manganlo is currently still practiced by some farmers, but some have begun to leave this tradition. Doing work together is still often done by farmers in this village, but now some have put in place a wage system, namely paying others in the process of working in the garden with some money.

In the process of planting, there are no different things that are done by Gayo coffee farmers by planting coffee in general. However, there is some local knowledge that is useful for protecting coffee plants later, such as plantation land which is first planted with several species of trees and not haphazardly, including avocado trees, lamtoro trees or Chinese petai trees. In Temas Mumanang village, dominant coffee farmers prefer to plant Chinese banana / lamtoro trees and pokat trees, although there are also some lands where lamtoro trees grow. Chinese petai trees and avocado trees are not important commodities used by their fruits, but the existence of avocado trees and Chinese petai trees or lamtoro trees is understood by farmers as the best tree species in protecting coffee plants from direct sunlight which can damage plants, but the leaves that are not too dense cause sunlight to still be able to hit the coffee tree, thus the plant can still benefit indirectly.

Farmers believe that if the coffee plants are not protected by these tree species, what will happen is damage to the coffee beans, so the coffee production will be poor and the quality cannot be maintained. Sunlight which directly leads to coffee plants without being hindered by anything is also not good because it can cause coffee to become dry. Not only that, the leaves that fall from shade trees/protectors are considered to be fertilizer for coffee plants. So we can always find in every coffee plantation land in the village area of Temas Mumanang in particular and in the area of Bener Meriah district, in general, there are always species of these trees. Coffee plants are plants that need a lot of water intensity. Farmers acknowledge that harvests are often not timely when rain also rarely occurs. 
Fortunately, the cold and humid climate conditions in the Gayo Highlands region make this region rarely experience a long dry season that damages the coffee plantations. However, sometimes it also happens, it does not rain after the emergence of the coffee fruit. While waiting for the ripe fruit, the coffee plant needs rain, without rain, the harvest will fail because the fruit does not develop. Conversely, plants that are continuously rained will also cause crop failure as well, because the fruit will runny and rotten. Therefore, until now there has not been a single technology capable of helping the situation of farmers related to this environmental situation, so the local relies heavily on climate.

Maintenance and attention to coffee plants according to farmers can not be said to be difficult as well and can not be said to be easy. One of them is the need for special attention and focus on the growth of shoots of coffee plants. The top of the coffee plant must be periodically cut so as not to damage the coffee beans that have been in the bottom because the height of the plant causes the nutrients that the plant has to spread to its branches, where some are unproductive. Too many branches will also produce a lot of fruit, so the number of nutrients available will be less absorbed in each fruit so that the fruit will not grow optimally. Farmers also need to keep coffee plants from being too high, because in the end, it will make coffee difficult to harvest.

Aside from keeping the coffee stems from getting too high, there is also local wisdom of the farmers associated with the stems of this plant, which is to remove/discard potential shoots that grow on stems called ceding (shoots). Every time ceding arises, usually farmers will pull it out. Because ceding will cause plants to grow upward. In addition to ceding, local farmers also know several other forms of branches that they must dispose of because they will interfere with the growth of their coffee plants. This knowledge rests on the local wisdom they have obtained from the previous generation. The branches that must be removed include: prone branches (male branches), which are branches that are not expected to be productive because of their abnormal growths as coffee tree branches generally; balek branch (turned), that is the branch whose leaf direction is turned toward the plant stem, not sideways; finger branch (shaped like a finger expands), which is considered to consume food branches because it is too big.

Special attention to coffee plants is also related to pests and wild plants such as thatch. For pests, farmers usually already have drugs that can eliminate these pests, but on the thatch, it turns out the farmers have their wisdom by not pulling it out or spraying weed eradicating liquid. The farmers in Temas Mumanang Village have the wisdom of executing these weeds. Usually, farmers will only cut the middle part of the weeds. From the farmer's explanation, most missteps are pulling or spraying liquid that can kill the weeds. Reeds are plants that contain a lot of water, so the most appropriate step is to cut with scissors in the middle of the plant so that later it will issue water that is useful for the coffee plant itself. The need for water in coffee can be helped although not much. Crops that have been cut will usually die by itself. So that it can provide benefits first before the weeds die. This method is still understood as the right step by farmers in maintaining coffee plants.

In the process of cultivating coffee plants, local farmers also have a culture that relies on local wisdom known as "peger ni keben". Peger ni keben has the meaning "peger" means fence (which is guarding), "keben" (rice barn). This means maintaining a sustainable food supply. To maintain their food supply, coffee farmers in almost all regions of the Gayo Highlands also plant several other food crops such as cassava (gadung), yams (kepile), pumpkin (petukel), banana ( $a w a l)$, in addition to coffee gardening.

Cultivation of these plants is usually done between the coffee plants that are in the process of waiting to be harvested. The aim is to plant several types of food plants between the coffee 
plants, none other than for food reserves if at any time primary food is scarce. This needs to be done by farmers, bearing in mind, when a coffee plant is started to be cultivated it cannot immediately produce results. They have to wait around 2.5 to 3 years to be able to collect coffee yields. During the waiting period, the farm family gets food reserves from the interrupting plant. As the name suggests, this peger ni keben usually contains alternative food crops that can prevent farmers and their families from starving because they are not only used when their coffee plants have not yet succeeded but can also become reserves during the famine, crop failure due to unfavorable climate.

The peak harvest season for coffee fruit in the district of Bener Meriah usually occurs in two periods in a year, the first period which is between March - June, and the second peak harvest takes place between October - December. However, the right time for peak harvest in this region does not always take place the same, this is because the coffee harvest time is determined by the intensity of the rainfall and heat of the sun. Thus, the peak harvest in the village of Temas Mumanang / Permata sub-district is about 2 weeks faster or slower than in other districts in the same district. Once again here is emphasized on whether or not the intensity of rain in each place.

In the harvesting system, all steps are considered to need caution because it can affect the coffee beans that are still buds will later grow. If you are not careful, the fruit that still buds will fall off and have an impact on the growth and yield of coffee in the next period. So that during the time of harvesting activities, farmers always remind families and workers who are paid to be more careful, for example in the way of picking coffee beans which must be done carefully. Until now farmers in the Gayo Highlands still do the picking process manually. This situation is different from the situation in coffee plantations assisting coffee picking machines. According to farmers, the use of coffee picking machines is ineffective, because as previously explained, coffee plants in Gayo are maintained so that they are not too high, so they are still affordable for direct picking. The use of a machine will also pick coffee fruit without sorting whether the fruit is ripe or still green.

Coffee picking cannot be done by cutting the branches directly to be taken by the fruit. This method not only damages the coffee tree itself but also makes coffee that is still green will fall. How to pick coffee beans from the stem also has a certain technique because the coffee can not be picked simultaneously. Three types of forms of coffee can be harvested, colored red, yellow and green. Fruits that can be harvested are those that are already red, it's just that usually farmers will also pick yellow fruit. This is not independent of the extent of plantation land so that later it will be difficult to pre-harvest the yellow fruit. So farmers continue to pick it by predicting that within a few days later the fruit can also be harvested. While the green colored fruit is considered not old enough and should not be picked because it is considered to reduce the quality of the coffee itself if picked as a whole. picked at the next picking at the same harvest period. In the implementation of picking this fruit, one harvest will be done several times with a grace period of about two weeks. The picking process is also related to the vulnerable time that should not be too long or too fast from the time of picking that has been done before because it is considered to reduce the quality of the coffee.

Another local wisdom of Gayo coffee farmers related to the picking process is the technique to start picking coffee from the bottom/valley to the top of the hill. This is done so that they do not need to go back and forth lifting buckets containing coffee fruit yields that are usually heavy, Since usually, the farmer's house is on the high ground (hill), then the process of picking coffee from the valley towards the hill causes them to be abler save energy. Then they will go zigzagged. With this step, no coffee trees will be passed by the harvest. The following picture is the plot of plucking coffee that is ready to be harvested. 


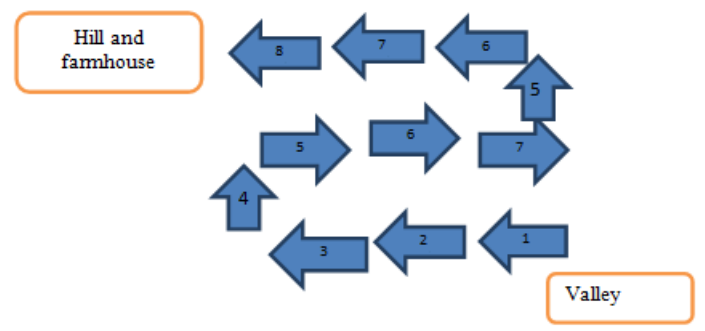

Fig. 1. The flow of coffee picking

Farmers will usually instruct their families, relatives and other people who are hired/paid for the wages of picking coffee to follow this harvesting system. But sometimes, the unequal harvesting time for each plant also causes the picking groove to experience slight changes that don't have to be like the pattern in the picture but still start from the lower region to the upper region. So that if some fruits are tucked and not harvested, they can be monitored well by the farmers.

\section{Conclusion}

The farming system applied by Gayo Coffee farmers in Temas mumanang village, Permata District, Bener Meriah Regency has two opposing sides but can also complement each other. That can be both local and global. In managing crop yields, modern tools have been used to speed up the management process to get the best coffee yields. It's just that at other pre-harvest stages, farmers still apply forms of local knowledge in their management system. This can be seen from the stage of land clearing by carrying out festivity and providing clean offerings. Then the pre-planting stages of coffee are first required to plant several types of coffee-protecting trees, namely avocado tree, Lamtoro tree/ Chinese banana tree. Besides, the process of maintenance and harvesting also applies a form of local knowledge in its completion.

This local knowledge is also experiencing problems in its existence. It started eroded and replaced with more modern global knowledge. The problems faced by farmers are not only related to the existence of local wisdom but also related to the labor of workers who are gradually getting smaller and also asking for a fairly high fee. This is inseparable from the many workers who have turned into coffee landowners as well. So that the owners of agricultural land often experience difficulties when the process of harvesting.

\section{References}

[1] Puspitawati, "Cultural Change of Change of Coffee Farmer Society in Gayo Highlands, Indonesia," vol. 5, no. 11, pp. 46-56, 2017.

[2] E. dan S. Banowaty, Geografi Pertanian. Jakarta: Ombak, 2013.

[3] O. Tirsa, "Praktik-Praktik Kearifan Lokal dalam Pengelolaan Sumber Daya Pertanian Padi Sawah," Institut Pertanian Bogor, 2012.

[4] N. A. Ridwan, "Landasan Keilmuan Kearifan Lokal,” J. Stud. Islam dan Budaya, vol. 5, no. 1, pp. 1-8, 2007.

[5] O. Soemarwoto, Ekologi, Lingkungan Hidup, dan Pembangunan. Jakarta: Djambatan, 2004. 
[6] E. Y. dan R. P. Sukmawati N., "Studi etnobotani tumbuhan obat pada masyarakat suku Kaili Rai di desa Toga kecamatan Ampibabo Kabupaten Parigi Moutong Sulawesi Tengah,” J. Biocelebes, vol. 7, no. 2, pp. 9-14, 2013.

[7] A. Susilawati and D. Nursyamsi, "Sistem Surjan: Kearifan Lokal Petani Lahan Pasang Surut dalam Mengantisipasi Perubahan Iklim. Jurnal Sumber Daya Lahan," J. Sumber Daya Lahan, vol. 8, no. 1, 2014.

[8] C. S. Damanik and K. Cepriadi, "Strategi Mempertahankan Kearifan Lokal Petani Sawah di Desa Bungaraya Kecamatan Bungaraya Kabupaten Siak," J. online Mhs. Bid. Pertan., vol. 3, no. $1,2016$.

[9] Nurjannah, T. Simarmata, Supsiloani, T. Andayani, A. Febryani, and B. K. Amal, "The Implementation of Local Wisdom Education Global Insights in Institutional and Local Wisdom of Culture in North Sumatera Subject in Faculty of Social Science,Universitas Negeri Medan," vol. 208, no. Icssis 2018, pp. 138-143, 2019.

[10] Arkanudin, Sistem Perladangan dan Kearifan Tradisional Orang Dayak dalam Mengelola Sumber Daya Hutan. Bandung: Pascasarjana Universitas Padjadjaran, 2001.

[11] Iskandar, Metodologi Penelitian Kualitatif. Jakarta: Gaung Persada Press, 2009.

[12] J. P. Spradley, Metode Etnografi. Yogyakarta: Tiara Wacana, 2007. 